\title{
Pengaruh Bahan Pengisi Kemasan Terhadap Kerusakan Fisik Pada Buah Pepaya (Carica papaya L.) Selama Transportasi Laut.
} (The Influence of Packaging Fillers on Physical Damage to Papaya Fruits (Carica papaya L.) During Sea Transport.)

\author{
Muazzimi $^{1}$, Kiman Siregar ${ }^{1}$, Bambang Sukarno Putra $^{{ }^{*}}$ \\ ${ }^{1}$ Program Studi Teknik Pertanian, Fakultas Pertanian, Universitas Syiah Kuala
}

\begin{abstract}
Abstrak. Salah satu ciri komoditas hortikultura termasuk pepaya adalah sifatnya yang mudah rusak (perishable) seperti mudah busuk dan mudah susut bobotnya karena kulitnya yang tipis dan daging buahnya yang lunak. Dari hasil penelitian kerusakan fisik yang yang terendah terdapat pada alat transportasi kapal cepat dengan perlakuan bahan pengisi kemasan yang menggunakan bahan pengisi daun pisang kering, dan dari hasil uji BNT bahan pengisi yang bagus adalah daun pisang kering, dikarenakan daun pisang kering berbentuk lentur dan suhu dari daun pisang kering tersebut netral. Susut bobot setelah transportasi yang paling sedikit terjadinya kehilangan pada kapal lambat dengan perlakuan tanpa bahan pengisi, hanya sedikit selisih dengan alat transportasi kapal cepat bahan pengisi daun pisang kering.Nilai vitamin $\mathrm{C}$ yang tertinggi adalah 11,6 yang diperoleh pada perlakuan kapal cepat dengan bahan pengisi styrofoam. Tingkat kesukaan panelis terhadap rasa dan warna pada perlakuan kapal lambat dengan bahan pengisi styrofoam, sedangkan nilai terendah ada pada perlakuan kapal lambat tanpa bahan pengisi, rasa dan warna sangat berhuhungan sehingga nilai tertinggi terdapat pada perlakuan yang sama dan juga hasil terendah.
\end{abstract}

Kata kunci : Pepaya, kerusakan buah, kapal.

Abstract. One characteristic of horticultural commodities including papaya is its perishable nature as it is easy to rot and easily shrinks its weight due to its thin skin and soft flesh. From the result of the research, the lowest physical damage was found in fast ship transportation by the treatment of packing material using dry banana leaf filler, and from the BNT test the good filler was dried banana leaf, due to dry banana leaf-shaped bending and temperature from Dry banana leaves are neutral. Weight loss after transport with the least loss of slow-moving vessels with no filler treatment, only slight difference with the rapid vessel transport filling of dried banana leafs. The highest vitamin C value was 11.6 obtained in the treatment of fast vessels with fillers Styrofoam. The panelist's favorite level of taste and color in the treatment of slow vessels with styrofoam fillers, while the lowest values are in slow ship treatment without fillers, the flavors and colors are highly respected so that the highest value is in the same treatment and also the lowest yield.

Keywords: Papaya, fruit damage, ship.

\section{PENDAHULUAN}

Pengembangan budidaya pepaya secara intensif dan komersial memiliki prospek yang cerahPepaya merupakan buah tropika yang baik bagi daya tahan tubuh di daerah tropis karena juga banyak mengandung Vitamin C, Vitamin A, Gula, dan Mineral-mineral lainnya seperti Kalsium, Fosfor, dan Besi yang dibutuhkan oleh tubuh manusia. Sebagai komoditas buah penting, pepaya memiliki berbagai keunggulan, yaitu cepat berproduksi, mampu berbuah sepanjang tahun, dan tidak memerlukan lahan penanaman yang luas sehingga dapat ditanam di pekarangna rumah. Disisi lain

Secara fisik tekstur buah pepaya sangat lembut dan mudah rusak karenanya dalam perdagangan nasional dan internasional buah ini berada jauh dibelakang pisang dan nenas. Oleh karena itu mempertahankan mutu buah terutama setelah panen sangat penting sehingga buah dapat terhindar dari kerusakan fisik maupun kimia yang dapat menyebabkan kerusakan bauh yang lebih besar dan dapat menurunkan mutu buah (Mifra, 1994). 
Secara umum, proses pengangkutan buah pepaya dari produsen ke konsumen hanya dilakukan dengan kemasan yang sangat sederhana, seperti karung maupun keranjang bambu dengan penanganan yang sangat minimum. Perbaikan dalam pengemasan akan memberikan keuntungan yang besar bagi pemasaran buah pepaya. Hasil penelitian yang dilakukan oleh Ariyanti (2004) menunjukkan kerusakan mekanis buah pepaya yang dikemas dengan menggunakan bahan pengemas keranjang bambu mengalami kerusakan fisik 25-50\%, sedangkan buah pepaya yang dikemas dengan menggunakan bahan pengemas peti kayu dan yang dikemas dalam kotak karton mengalami kerusakan fisik 0$25 \%$.

\section{METODE PENELITIAN}

Penelitian dilakukan dengan cara pengujian langsung di lapangan, buah pepaya ditransportasikan langsung dari Pelabuhan Balohan Sabang ke Pelabuhan Ulee lhee Banda Aceh dengan menggunakan alat transportasi jalur laut dengan kapal fery dan Kapal express.

Buah pepaya siap panen dikumpulkan kemudian disortasi dan dilakukan pembersihan dari kotoran. Kemudian buah pepaya dimasukkan ke dalam kemasan kardus yang masing-masing dibedakan berdasarkan bahan pengisi kemasannya, yaitu kemasan tanpa bahan pengisi, kemasan dengan bahan pengisi daun pisang kering, dan kemasan dengan bahan pengisi styrofoam. Masing-masing kardus birisi 3 buah pepaya yang disusun dalam satu susunan vertikal. Kardus buah pepaya akan ditransportasikan melalui jalur laut menggunakan 2 alat transportasi yaitu kapal fery dan kapal express dengan jarak $22 \mathrm{~km}$ atau 14 mil dari Pelabuhan Balohan Kota Sabang menuju pelabuhan Ulee Lheue Kota Banda Aceh. Temperatur luar kardus diukur setiap 20 menit sekali selama perjalanan menggunakan termometer. Analisa mutu buah pepaya dilakukan di Banda Aceh yang meliputi analisis kerusakan fisik (memar, pecah, dan luka), kekerasan, susut bobot, uji organoleptik, dan total padatan terlarut. Penelitian ini merupakan RAL (Rancangan Acak Lengkap) faktorial dengan 2 faktor perlakuan yaitu, perlakuan bahan pengisi kemasan dengan 3 taraf (tanpa bahan pengisi, daun pisang kering, dan styrofoam ) dan jenis transportasi laut, dengan 2 taraf (kapal cepat dan kapal lambat). Penelitian ini dilakukan dengan 2 ulangan sehingga didapat 12 satuan percobaan.

Tabel 1.Susunan Kombinasi Perlakuan Penelitian.

\begin{tabular}{|c|c|c|c|}
\hline \multirow[b]{2}{*}{$\begin{array}{l}\text { Variasi } \\
\text { Kendaraan }\end{array}$} & \multicolumn{3}{|c|}{ Variasi Bahan Pengisi Kemasan } \\
\hline & $\begin{array}{l}\text { Tanpa bahan } \\
\text { Pengisi } \\
\text { Kemasan/ } \\
\text { Kontrol }\left(\mathbf{F}_{0}\right)\end{array}$ & $\begin{array}{l}\text { Daun pisang kering } \\
\left(F_{1}\right)\end{array}$ & $\begin{array}{c}\text { g Styrofoam } \\
\left(\mathrm{F}_{2}\right)\end{array}$ \\
\hline 1. Kapal cepat $\left(C_{1}\right)$ & $\begin{array}{l}\mathrm{C}_{1} \mathrm{~F}_{0}(1) \\
\mathrm{C}_{1} \mathrm{~F}_{0}(2)\end{array}$ & $\begin{array}{l}\mathrm{C}_{1} \mathrm{~F}_{1}(1) \\
\mathrm{C}_{1} \mathrm{~F}_{1}(2)\end{array}$ & $\begin{array}{l}\mathrm{C}_{1} \mathrm{~F}_{2}(1) \\
\mathrm{C}_{1} \mathrm{~F}_{2}(2)\end{array}$ \\
\hline 2. Kapal lambat $\left(C_{2}\right)$ & $\begin{array}{l}\mathrm{C}_{2} \mathrm{~F}_{0}(1) \\
\mathrm{C}_{2} \mathrm{~F}_{0}(2)\end{array}$ & $\begin{array}{l}\mathrm{C}_{2} \mathrm{~F}_{1}(1) \\
\mathrm{C}_{2} \mathrm{~F}_{1}(2)\end{array}$ & $\begin{array}{l}\mathrm{C}_{2} \mathrm{~F}_{2}(1) \\
\mathrm{C}_{2} \mathrm{~F}_{2}(2)\end{array}$ \\
\hline
\end{tabular}


Adapun model matematisnya adalah sebagai berikut :

$\mathrm{Y}_{\mathrm{ijk}}=\mu+\mathrm{F}_{\mathrm{i}}+\mathrm{C}_{\mathrm{j}}+(\mathrm{CF})_{\mathrm{ij}}+\boldsymbol{\varepsilon}_{\mathrm{ijk}}$

$\mathrm{Y}_{\mathrm{ijk}}$ : Hasil pengamatan variasi kendaraan (F) faktor ke-i dan variasi bahan pengisi kemasan (C) pada taraf ke-j pada ulangan ke-k.

$\mu \quad$ : Nilai rata-rata umum

$\mathrm{C}_{1} \quad$ : Pengaruh variasi kendaraan

$\mathrm{F}_{\mathrm{j}} \quad$ : Pengaruh variasi bahan pengisi kemasan

$(\mathrm{CF})_{\mathrm{ij}}$ : Pengaruh interaksi antara variasi kendaraan ke-i dari faktor $\mathrm{F}$ dan variasi bahan pengisi kemasan ke-j dari faktor $\mathrm{C}$

$\varepsilon_{\mathrm{ijk}} \quad$ : Galat percobaa

Data yang diperoleh dianalisis dengan uji ANOVA. Apabila terdapat pengaruh nyata maka akan diteruskan dengan uji BNT.

BNT $(5 \%, 1 \%)=$ Tabelt $(\mathrm{db}) \frac{\sqrt{2(\mathrm{KTA})}}{n}$

$\mathrm{db} \quad$ : Derajat Bebas

KTA : Kuadrat Tengah Acak

$\mathrm{n}$ : Jumlah Ulangan

$\mathrm{t} \quad$ : Jumlah Perlakuan

\section{HASIL DAN PEMBAHASAN}

\section{Kerusakan fisik}

penelitian ini proses perhitungan kerusakan fisik buah pepaya bertujuan untuk melihat keutuhan buah.

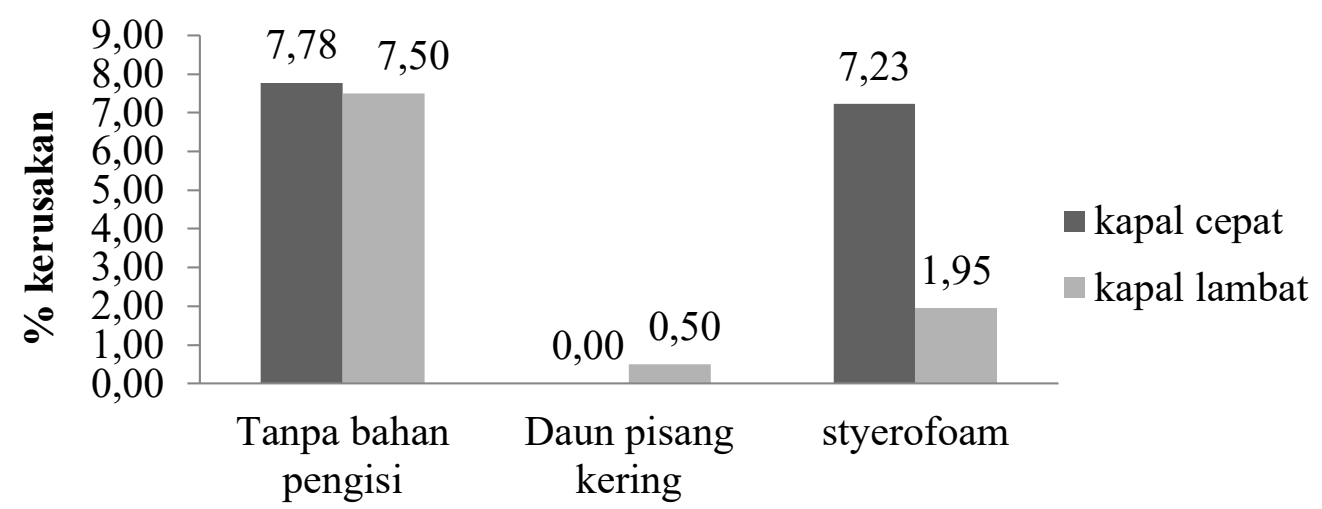

\section{Kemasan}

Gambar 1. (\%) kerusakan buah pepaya rata-rata

Pada Gambar 1. dapat dilihat bahwa buah pepaya pada transportasi menggunakan kapal cepat dan kapal lambat memiliki tingkat kerusakan yang berbeda-beda. Pada transportasi menggunakan kapal cepat, pepaya yang dikemas tanpa bahan pengisi memiliki tingkat kerusakan sebanyak $7,8 \%$, buah pepaya yang dikemas dengan bahan pengisi daun pisang kering memiliki persentase kerusakan sebanyak $0,0 \%$ dan buah pepaya yang dikemas dengan bahan pengisi styrofoam memiliki persentase kerusakan sebanyak 7,2\%. 
Sedangkan pada transportasi kapal lambat kerusakan buah pepaya yang dikemas tanpa bahan pengisi memiliki persentase sebanyak $7,5 \%$, pepaya yang dikemas menggunakan daun pisang kering memiliki kerusakan sebanyak $0,5 \%$ dan pepaya yang di kemas menggunakan styrofoam memiliki persentase kerusakan sebanyak 1,9\%. Secara keseluruhan nilai persentase kerusakan buah pepaya tertinggi terdapat pada buah pepaya yang dikemas tanpa bahan pengisi dengan menggunakan transportasi kapal cepat, sedangkan kerusakan terendah terdapat pada buah pepaya yang dikemas menggunakan daun pisang kering dengan transportasi menggunakan kapal lambat..

\section{Memar}

Dari hasil penelitian presentase memar terbesar terjadi pada pepaya yang menggunakan kapal cepat sebagai alat transportasi dan menggunakan styrofoam sebagai bahan pengisi kemasan.

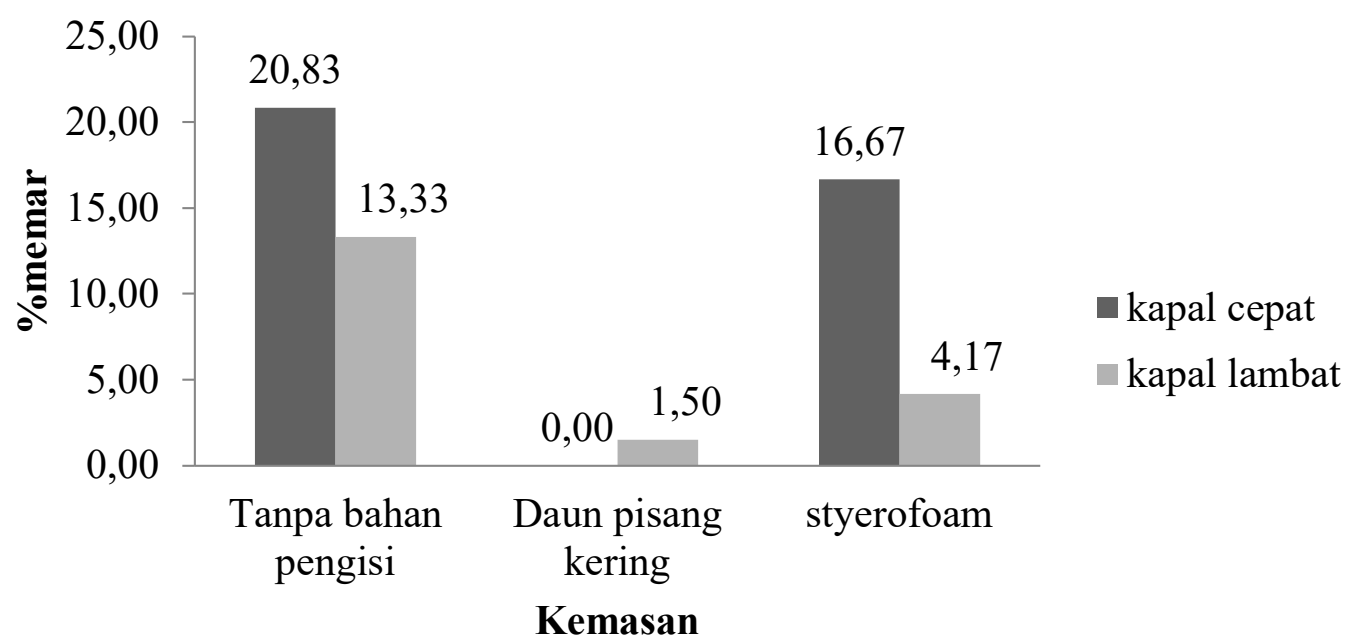

Gambar 2. (\%) Memar buah pepaya rata-rata

Bedasarkan gambar persentase memar pada Gambar 2. Dapat dilihat kemasan buah buah pepaya pada kapal cepat bahan pengisi daun pisang kering tidak terjadi memar dengan persentasi $0 \%$, berarti $100 \%$ tidak terjadi memar pada buah pepaya, sedangkan persentase yang paling tinggi terjadi memar buah pada kapal cepat tanpa bahan pengisi dengan persentase $20,83 \%$ berarti $79.17 \%$ yang tidak memar pada kapal cepat bahan pengisi daun pisang kering.

\section{Pecah}

Pada penelitian yang telah dilakukan buah pepaya yang di transportasikan menggunakan kapal cepat maupun kapal lambat tidak mengalami kerusakan fisik berupa pecah, dikarenakan tidak adanya tekanan yang over sehingga buah pepaya yang di transportasikan tidak ada yang mengalami pecah.

\section{Luka}

Pada penelitian yang telah dilakukan buah pepaya yang ditransportasikan mengguanakan kapal cepat maupun kapal lambat . 


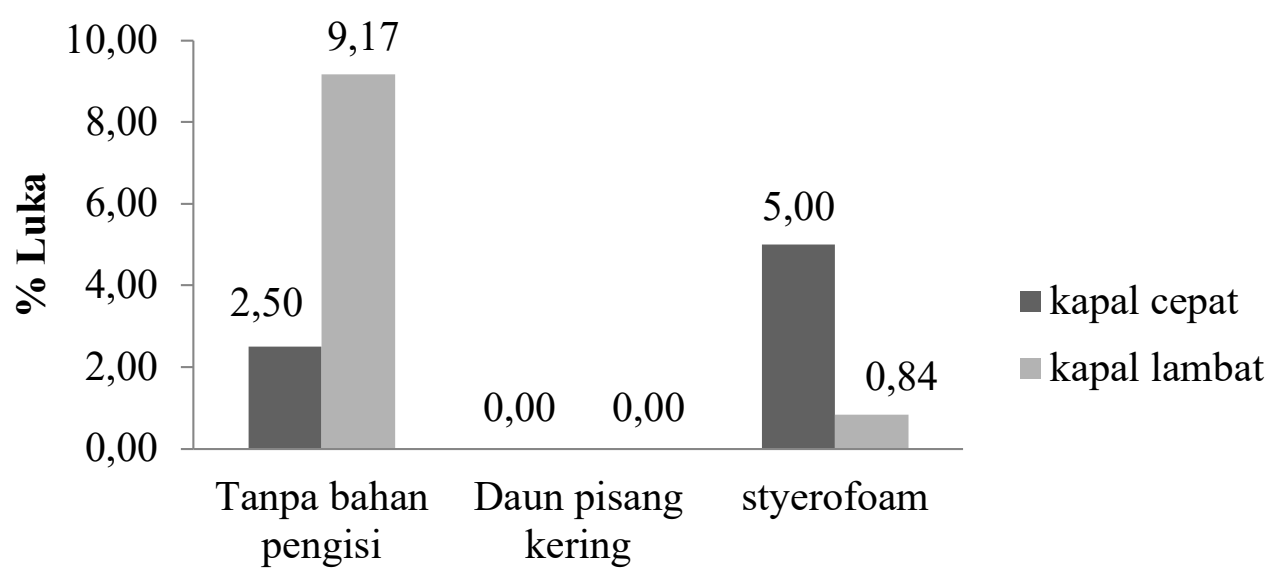

\section{Kemasan}

Gambar 3. (\%) Luka buah pepaya rata-rata

Bedasarkan gambar persentase luka pada Gambar 3. Dapat dilihat kemasan buah buah pepaya pada kapal cepat dan lambat bahan pengisi daun pisang kering tidak terjadi memar dengan persentasi $0 \%$, berarti $100 \%$ tidak terjadi luka pada buah pepaya, sedangkan persentase yang paling tinggi terjadi luka buah pepaya pada kapal lambat tanpa bahan pengisi dengan persentase $9,17 \%$.

\section{Kekerasan}

Kekerasan ialah proses pelunakan kulit ataupun daging pada buah yang diakibatkan oleh rusaknya sel-sel pada buah. Menurut Lakitan (1995), bahwa kekerasan dikatakan baik bukan karena nilai kekerasannya terlalu tinggi atau rendah, akan tetapi tergantung pada fisiknya. Kekerasan buah yang tinggi bisa disebabkan karena tekstur buahnya yang sudah layu atau berkerut. Nilai persentase kekerasan buah naga dapat dilihat pada Gambar 4 .

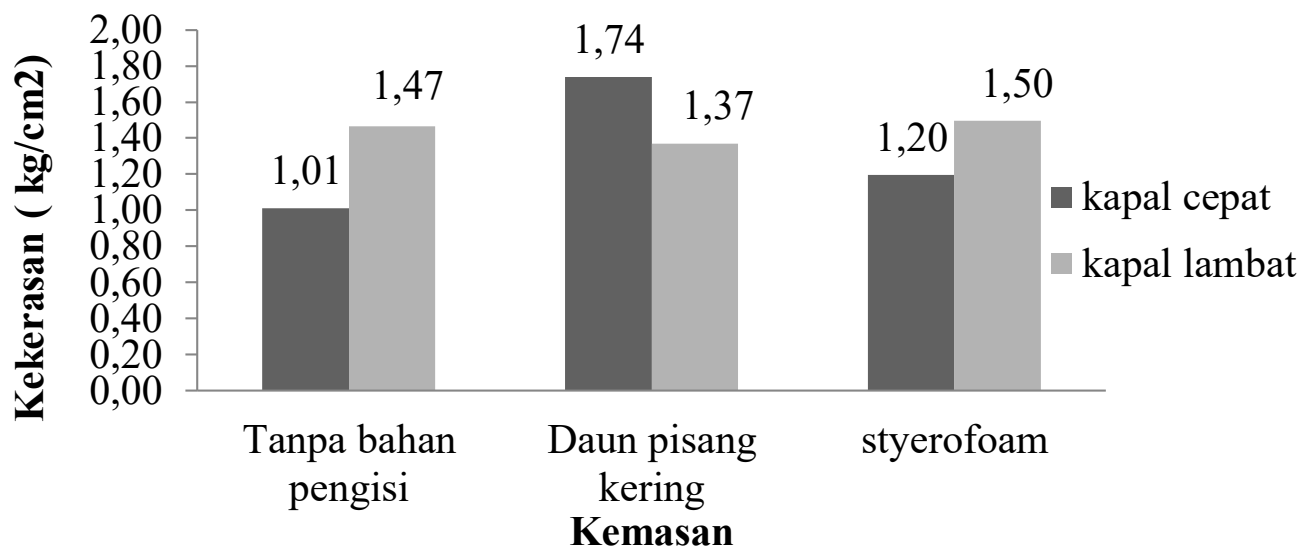

Gambar 4. Nilai Kekerasan Buah Pepaya Sesudah Transportasi Akibat Variasi Kendaraan Dan Bahan Pengisi Kemasan 
Data dari hasil pengamatan menunjukkan perbedaan kekerasan pada buah pepaya, dimana tingkat kekerasan terendah ada pada kapal cepat tanpa bahan penigisi dengan nilai kekerasan $1,0 \mathrm{~kg} / \mathrm{cm}^{2}$ dan nilai kekerasan yang tertinggi adalah dengan menggunakan kapal cepat dengan bahan pengisi daun pisang kering dengan nilai $1,74 \mathrm{~kg} / \mathrm{cm}^{2}$. Hal ini disebabkan karena stuktur kulit buah pepaya menjadi semakin lunak akibat terjadinya respirasi pada buah pepaya selama perjalanan, adanya getaran yang dihasilkan oleh alat transportasi dan juga suhu yang mempengaruhi buah pepaya.

\section{Susut bobot}

Menurut Gardjito $d k k$. (2003), susut bobot merupakan hal yang sangat jelas merugikan karena langsung mengurangi hasil penjualan dikarenakan susut bobot berkurang. Untuk meminimalisirkan masalah tersebut di perlukan keterampilan dalam memperkirakan besar susut bobot selama penyimpanan dan pemasaran komoditi hortikultura.

Dalam penelitian ini proses perhitungan susut bobot buah pepaya bertujuan untuk melihat kehilangan berat pada buah pisang selama transportasi.

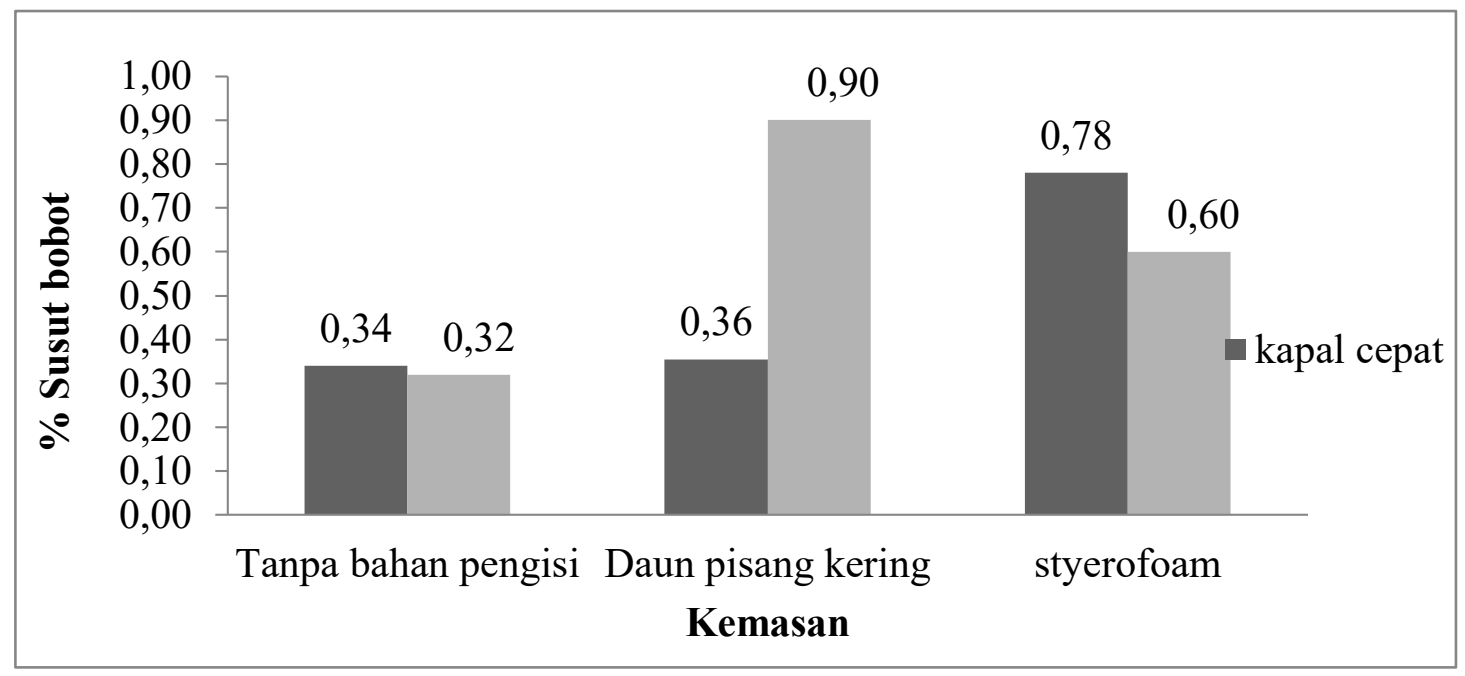

Gambar 5. Susut Bobot Buah Pepaya Setelah Transportasi

Pada hasil penelitian menunjukkan bahwa susut bobot terbesar terjadi pada buah pepaya yang menggunakan transportasi kapal lambat dan menggunakan bahan pengisi daun pisang kering sebesar $0,90 \%$. Sebaliknya persentase susut bobot terkecil terjadi yang menggunakan kapal lambat tanpa bahan pengisi yaitu $0,32 \%$.

\section{Temperatur}

Temperatur selama transportasi pada penelitian ini bervariasi, masing- masing kemasan memiliki variasi temperatur yang berbeda. Namun demikian fluktuasi temperatur antara masing-masing kemasan tidak terlalu jauh perbedaan nya. Gambar 6 . Memperlihatkan distribusi temperaturpada masing-masing perlakuan baik temperatur lingkungan maupun temperatur kotak kemasan. 


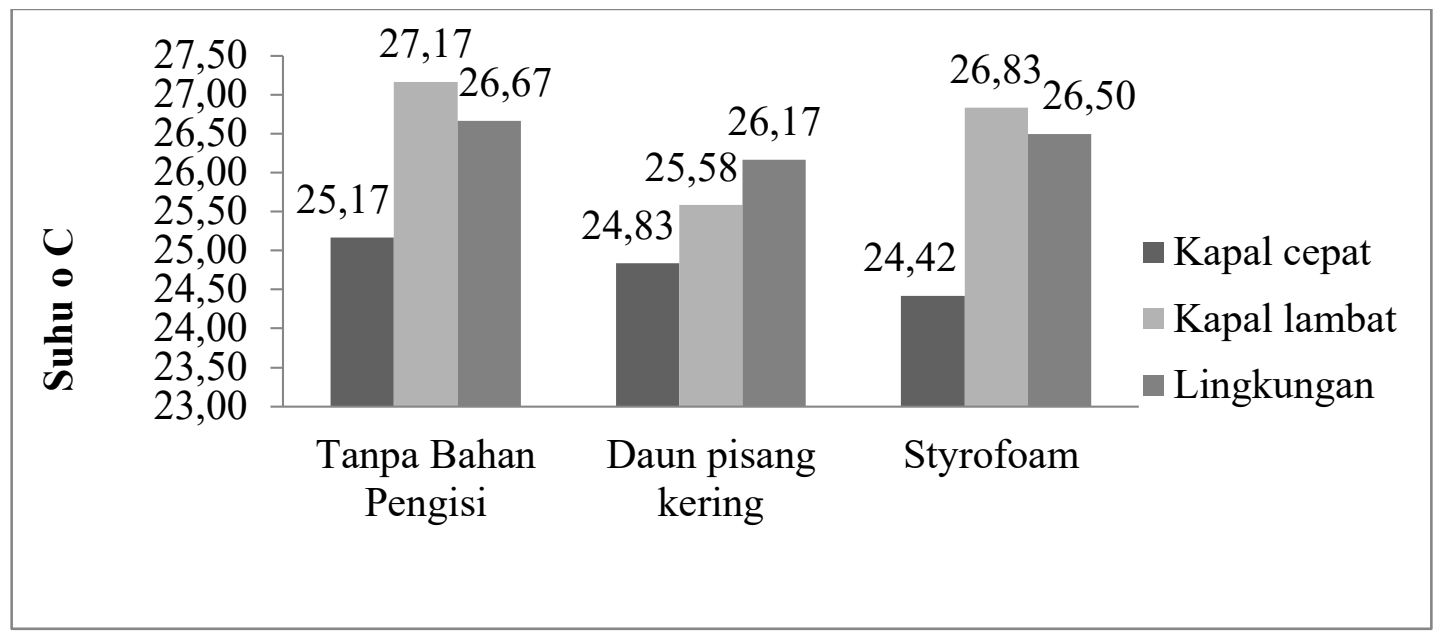

Gambar 6. Grafik temperatur kotak dan lingkungan selama transpotasi.

Pada penelitian ini di peroleh data sebagai berikut: pada kemasan buah pepaya tanpa bahan pengisi kemasan yang diangkut menggunakan kapal lambat diperoleh nilai temperatur ratarata dalam kotak sebesar $27,17^{\circ} \mathrm{C}$, sedangkan kemasan buah pepaya tanpa bahan pengisi yang diangkut menggunakan kapal cepat diperoleh nilai temperatur sebesar $25,17^{\circ} \mathrm{C}$.

Pada kemasan buah pepaya dengan bahan pengisi kemasan daun pisang kering yang diangkut menggunakan kapal lambat diperoleh nilai temperatur rata-rata dalam kotak sebesar $27,00^{\circ} \mathrm{C}$, sedangkan kemasan buah pepaya yang bahan pengisi daun pisang kering diangkut menggunakan kapal cepat diperoleh nilai rata-rata temperatur sebesar $24,83^{\circ} \mathrm{C}$.

Pada kemasan buah pepaya dengan bahan pengisi kemasan menggunakan styrofoam yang diangkut menggunakan kapal lambat diperoleh nilai temperatur rata-rata dalam kotak sebesar $26,83^{\circ} \mathrm{C}$, sedangakan kemasan buah pepaya bahan pengisi kemasan styrofoam yang diangkut menggunakan kapal cepat di peroleh nilai temperatur sebesar $24,42^{\circ} \mathrm{C}$.

Temperatur lingkungan rata-rata yang diperoleh selama transportasi pada jenis kapal yang digunakan kapal lambat adalah $27,33^{\circ} \mathrm{C}$, sedangkan pada kapal cepat temperatur ratarata lingkungannya yaitu sebesar $25,67^{\circ} \mathrm{C}$. Dalam proeses transpotasi perbedaan temperatur lingkungan dengan temperatur kotak diakibatkan oleh aliran udara mengalir pada kotak lebih stabil karena dengan adanya ventilasi yang memadai sehingga temperatur lingkungan lebih tinggi dan temperatur pada kotak lebih rendah.

\section{(TPT) Total Padatan Terlarut}

Total Padatan Terlarut (TPT) merupakan faktor mutu yang bisa digunakan untuk analisis mutu buah. Metode untuk menduga Total Padatan Terlarut (TPT) selama penyimpanan dapat dilakukan dengan mengguanakan alat hand refrcractometer untuk uji TPT. Buah yang masih terlalu muda mempunyai kandungan gula yang kurang dan hanya sedikit asam, yang mengakibatkan perbandingan Total Padatan Terlarut dengan asam tinggi. Dengan semakin masaknya buah, TPT bertambah (Pantastico, 1989).

Total Padatan Terlarut (TPT) merupakan faktor mutu yang bisa digunakan untuk analisis mutu buah. Metode untuk menduga Total Padatan Terlarut (TPT) selama penyimpanan dapat dilakukan dengan mengguanakan alat hand refrcractometer untuk uji TPT. 


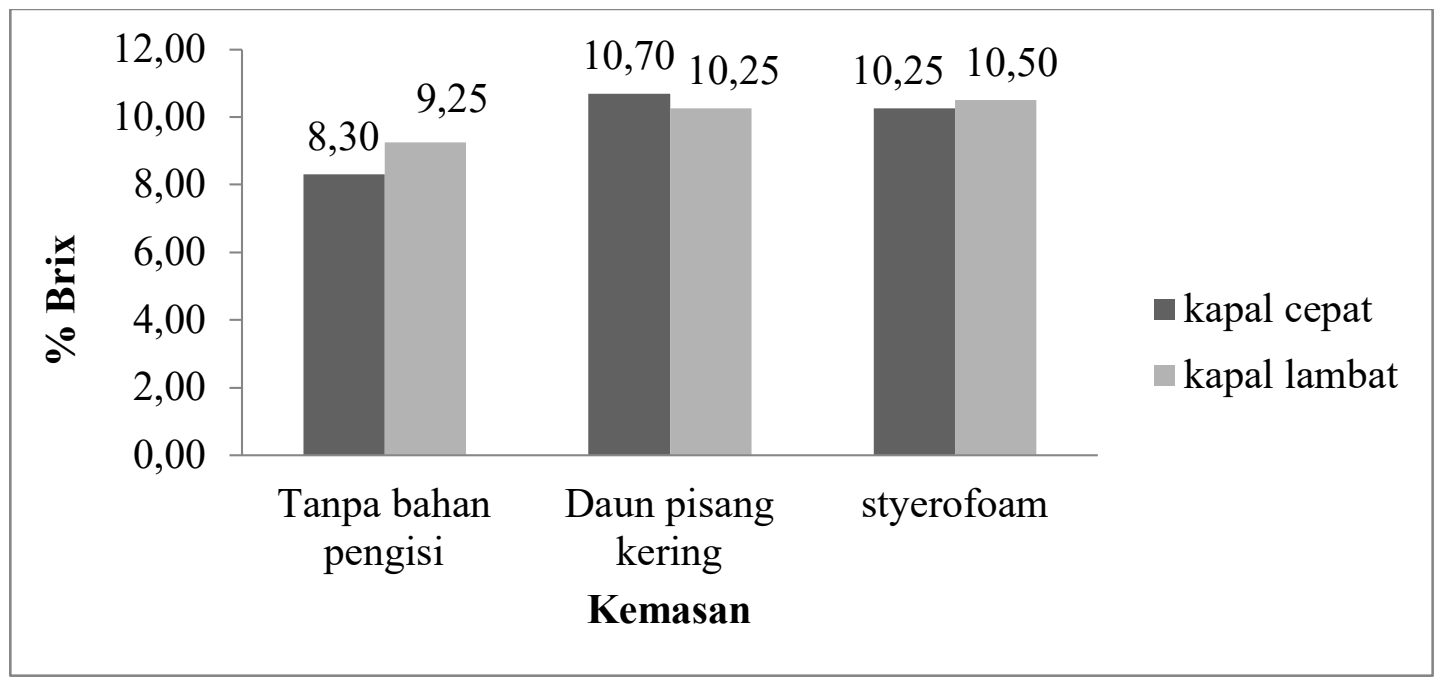

Gambar 7. Derajat kemanisan buah pepaya setelah transportasi dengan variasi alat transporatsi dan bahan pengisi kemasan.

Bedasarkan dari hasil penelitian yang dilakukan, total padatan terlarut buah pepaya yang tinggi tedapat pada buah pepaya yang dikemas dengan mengguanakan daun pisang kering dan diangkut menggunakan transportasi kapal cepat dengan nilai $10,7{ }^{0}$ brix. Sedangkan nilai total padatan terlarut yang terendah diperoleh pada buah pepaya tanpa bahan pengisi dengan mengunakan transportasi kapal cepat dangan nilai $8,3^{\circ} \mathrm{brix}$.

\section{Vitamin C}

Pada kemasan dan bahan pengisi juga berpengaruh terhadap kehilangan kadar vitamin $\mathrm{C}$, apabila terjadinya kerusakan atau luka akan terjadinya penyusutan pada buah pepaya. Kerusakan ataupun luka terjadi kerna adanya benturan, gesekan dan getaran yang di akibatkan oleh faktor internal dan eksternal. Faktor internal seperti respirasi dan metabolisme dalam buah pepaya, sedangkan faktor eksternal seperti bahan pengisi, alat transportasi nilai vitamin C.

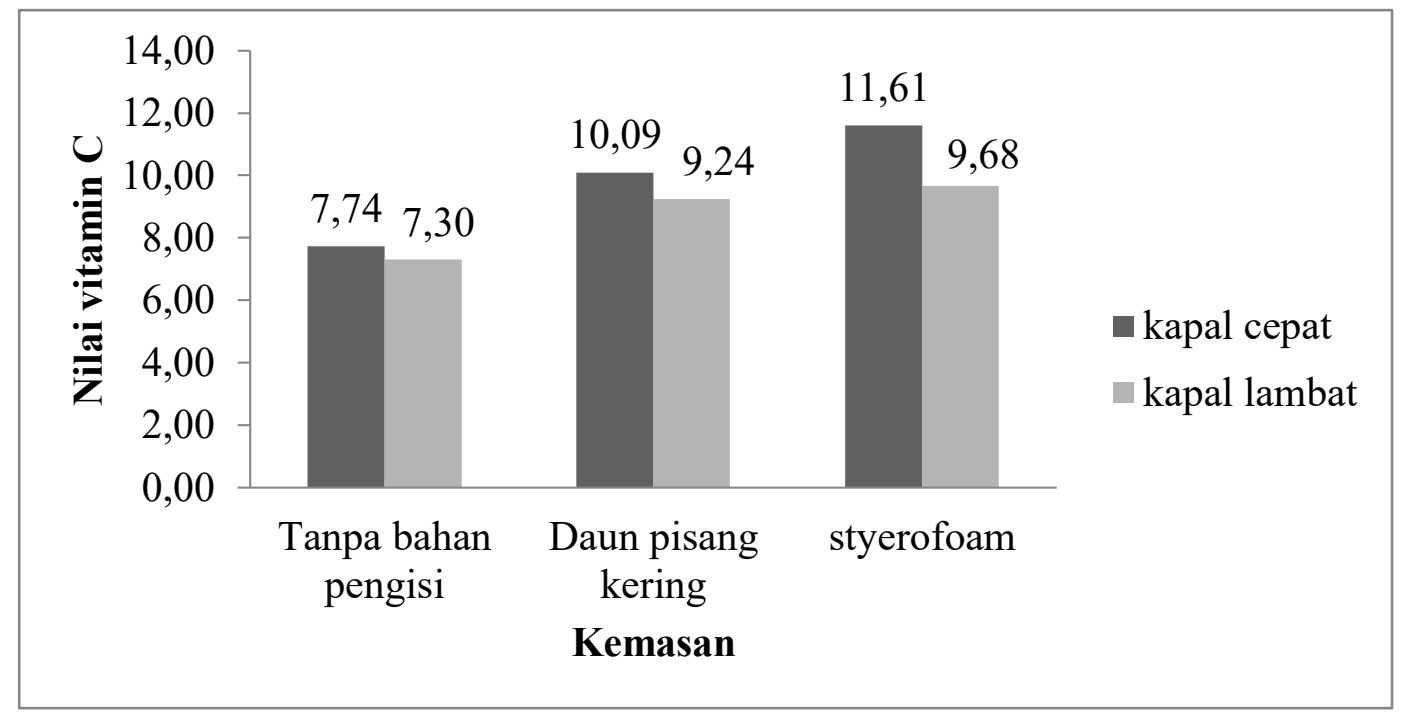

Gambar 8. Grafik vitamin C pepaya setelah transportasi dengan variasi alat transpotasi dan bahan pengisi. 
Dapat dilihat pada Gambar 8. Berdasarkan hasil analisis penelitian diketahui bahwa nilai vitamin $C$ setelah dilakukannya penjalanan menggunakan kapal lamabat dan kapal cepat dengan variasi bahan pengisi bahwa nilai vitamin $\mathrm{C}$ tetinggi terdapat pada kapal cepat dengan kotak bahan pengisi styrofoam dengan nilai 11,6. Sedangkan nilai vitamin $\mathrm{C}$ yang terendah terdapat pada kotak tanpa bahan pengisi menggunakan transportasi kapal lambat dengan nilai 7,7.

\section{Organoleptik}

Pada penelitian ini uji organoleptik menggunakan uji penerimaan menyangkut penilaian seseorang terhadap suatu sifat bahan sehingga menjadikannya kegemaran atau kesukaan. Untuk mengetahui nilai kesukaan konsumen dilakukan uji organoleptik dengan metode uji hedonik yang meliputi warna dan rasa. Panelis yang digunakan adalah panelis yang tidak terlatih sebanyak 20 orang mahasiswa. Nilai yang didapat pada uji organoleptik.

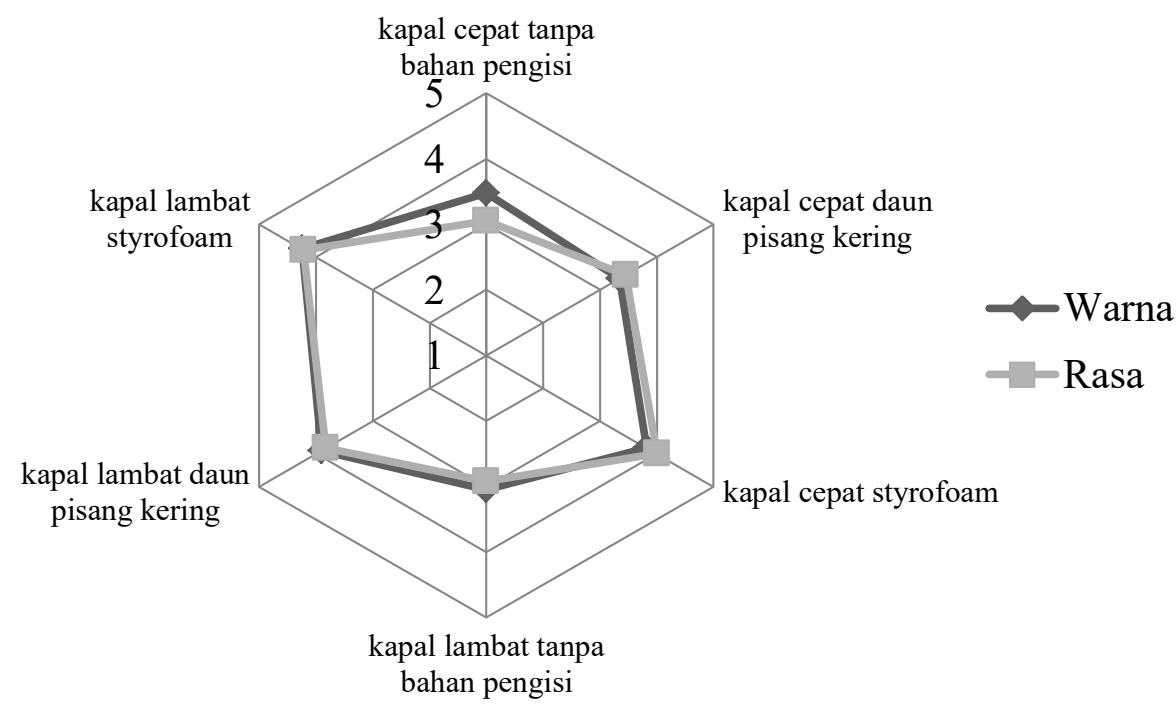

Gambar 9. Grafik oraganoleptik

Alat indra akan sifat-sifat benda karena adanya rangsangan yang diterima alat indra yang berasal dari Pengindraan diartikan sebagai suatu proses fisio-psikologis, yaitu kesadaran atau pengenalanbenda tersebut. Pengindraan dapat juga diartikan reaksi mental (sensatioan) jika alat indra mendapat rangsangan (stimulus). Reaksi atau kesan yang ditimbulkan karena adanya rangsangan dapat berupa sikap untuk mendekati atau menjauhi, menyukai, atau tidak menyukai akan benda penyebab rangsangan. Kesadaran, kesan dan sikap terhadapa rangsangan adalah reaksi psikologis atau reaksi subyektif atau penilain subyektif. Disebut penilaian subyektik karena hasil penilaian atau pengukuran sangat ditentukan oleh pelaku atau yang melakukan pengukuran.

\section{Warna}

Warna membuat produk pangan menarik, bagi makanan warna merupakan daya tarik utama sebelum konsumen mengenal dan menyukai sifat-sifat lainnya, dari warna dapat dilihat ciri dan jenis, tanda-tanda kematangan atau kerusakan dan dapat juga dijadikan sebagai parameter mutu. Warna memegang peranan penting dalam penerimaan produk oleh konsumen bersama-sama dengan aroma, kerenyahan, dan rasa (Soekarto, 1981). 
Pada gambar 9. Dapat dilihat tingakat kesukaan panelis terhadap warna yang dihasilkan tertinggi pada buah pepaya setelah transportasi adalah 4,25 pada perlakuan kapal lambat styrofoam. Hal ini dapat dipengaruhi oleh kematangan yang cepat kerena faktor repirasi yang terjadi dalam kotak yang mempengaruhi warna dengan tingkat kematangan, sedangkan nilai terendah kesukaan pada buah pepaya setelah transportasi adalah 3,05 pada kapal lambat tanpa bahan pengisi.

\section{Rasa}

Rasa merupakan hal yang sangat penting dan berpengaruh pada suatu komoditi, baik atau tidak baiknya rasa sebuah komoditi akan sangat menentukan diterima atau tidaknya sebuah komoditi oleh masyarakat. Dan rasa sebuah komoditi harus sangat diperhatikan sebelum produk diturukan ke pasar.

Dari uji organoleptik yang dilakuakan diperoleh data dengan tingkat kesukaan panelis tertinggi pada buah pepaya setelah transportasi adalah sebesar 4,23 pada perlakuan kapal lambat dengan bahan pengisi styrofoam. Hal ini bersangkutan dengan warna semakin tinggi nilai kesukaan pada warna maka juga berpengaruh terhadap rasa pada buah pepaya, sedangkan nilai terendah adalah adalah 2,93 yaitu pada perlakuan kapal lambat tanpa bahan pengisi.

\section{KESIMPULAN DAN SARAN}

Kerusakan fisik yang terendah terdapat pada transportasi kapal cepat dengan perlakuan bahan pengisi daun pisang kering sebesar 0,00\%. Nilai kekerasan yang tertinggi adalah dengan menggunakan kapal cepat dengan bahan pengisi daun pisang kering sebesar $1,7 \mathrm{~kg} / \mathrm{cm}^{2}$. Susut bobot setelah transportasi yang paling sedikit terjadinya kehilangan pada kapal lambat dengan perlakuan tanpa bahan pengisi sebesar $0,32 \%$.

Pada saat transportasi suhu kapal cepat lebih rendah dengan suhu rata-rata sebesar $25^{\circ} \mathrm{C}$, sedangkan suhu pada kapal lambat relatif lebih tinggi yaitu sebesar $27^{\circ} \mathrm{C}$. Tingkat kemanisan pada buah yang terbaik adalah pada kapal cepat bahan pengisi daun pisang dengan tingkat kemanisan 10,7. Nilai vitamin $\mathrm{C}$ yang tertinggi adalah 11,6 yang diperoleh pada perlakuan kapal cepat dengan bahan pengisi styrofoam. Tingkat kesukaan panelis terhadap rasa dan warna pada perlakuan kapal lambat dengan bahan pengisi styrofoam, sedangkan nilai terendah ada pada perlakuan kapal lambat tanpa bahan pengisi, rasa dan warna sangat berhuhungan sehingga nilai tertinggi terdapat pada perlakuan yang sama dan juga hasil terendah.

Sebaiknya dilakuakan jarak tempuh yang lebih lama agar hasil yang di dapatkan lebih terlihat pengaruhnya seperti meulaboh- sinabang. Perlu dilakukan penelitian dengan penambahan variasi bahan kemasan dan kemasannya. Sebaiknya dilakukan pengukuran kotak sama dengan komoditinya dan juga keseragaman komoditi.

\section{DAFTAR PUSTAKA}

Gardjito, M. Wardana, Agung S. 2003. Hortikultura, Teknik Analisis Pasca Panen. Transmedia Global Wacana, Yogyakarta

Pantastico, E.R.B. 1989. Fisiologi Pascapanen Penanganan dan Pemanfaatan Buahbuahan dan sayur-sayuran tropik dan subtropik. Gadjah Mada University Press. Yogyakarta.

Soekarto, S.T.. 1981. Penilaian Organoleptic Pusat Pengembangan Teknologi Pangan. IPB-Press, Bogor. 